\title{
Penerapan Terapi Musik Gamelan Jawa Terhadap Tingkat Kecemasan Pada Lansia Di Desa Wanarata Kecamatan Bantarbolang Kabupaten Pemalang
}

\author{
Celfi Khaerunisa Meliani ${ }^{1 *}$, Aisyah Dzil Kamalah ${ }^{2}$ \\ 1,2 Prodi Diploma Tiga Keperawatan, Fakultas Ilmu Kesehatan, Universitas Muhammadiyah \\ Pekajangan Pekalongan, Indonesia \\ *email: khaerunisa.meliiiani@gmail.com
}

\begin{abstract}
The elderly's anxiety can be caused by various causes. it includes threats to physical integrity resulting in physiological inability to carry out daily activities and threats to self-esteem that can cause damage to them and their integrity of social function. Javanese gamelan music therapy is an alternative therapy for the elderly with anxiety, especially those who experience mild to moderate anxiety which is very easy to do and without side effect. The purpose of thif paper is to determine the effect Javanese gamelan music therapy on anxiety levels in the elderly in Wanarata Village, Bantarbolang District, Pemalang Regency. The method used in this paper is a case study. Data were collected using the Geriatric Anxiety Scale (GAS) questionnaire. The result show that anxiety in the elderly has decreased. In client 1 and client 2, anxiety decreased from mild anxiety level (24-47) to no anxiety (0-23). Based on the result, it can be concluded that there is an effect of Javanese gamelan music therapy on the level of anxiety in the elderly. It is also suggested that nurses can provide Javanese gamelan music therapy to reduce anxiety in the elderly.
\end{abstract}

Keywords : Anxiety; elderly; gamelan music

\begin{abstract}
Abstrak
Kecemasan pada lansia disebabkan oleh berbagai macam penyebab, diantaranya adalah ancaman terhadap integritas fisik yang mengakibatkan ketidakmampuan fisiologis untuk melakukan aktifitas sehari - hari dan ancaman terhadap harga diri yang dapat merusak diri dan integritas fungsi sosial. Terapi musik gamelan Jawa adalah salah satu alternatif terapi pada lansia dengan kecemasan, terutama yang mengalami kecemasan ringan sampai sedang yang sangat mudah untuk dilakukan dan tanpa efek samping. Tujuan penulisan ini yaitu untuk mengetahui pengaruh terapi musik gamelan Jawa terhadap tingkat kecemasan pada lansia di Desa Wanarata Kecamatan Bantarbolang Kabupaten Pemalang. Metode pada karya tulis ini yaitu studi kasus. Pengambilan data menggunakan lembar kuesioner Geriatric Anxiety Scale (GAS). Hasil penerapan asuhan keperawatan pada lansia yang mengalami kecemasan dengan intervensi terapi musik gamelan Jawa menunjukkan kecemasan pada lansia mengalami penurunan. Pada klien 1 dan klien 2 kecemasan turun dari tingkat kecemasan ringan (24-47) ke tidak mengalami kecemasan (0-23). Simpulan : ada pengaruh terapi musik gamelan Jawa terhadap tingkat kecemasan pada lansia. Berdasarkan hasil penerapan tersebut maka disarankan perawat dapat memberikan terapi musik gamelan Jawa untuk menurunkan kecemasan pada lansia.
\end{abstract}

Kata kunci : Kecemasan; lansia; musik gamelan 


\section{Prosiding Seminar Nasional Kesehatan 2021 Lembaga Penelitian dan Pengabdian Masyarakat Universitas Muhammadiyah Pekajangan Pekalongan}

\section{Pendahuluan}

Lansia atau lanjut usia adalah perubahan yang terjadi pada manusia dari waktu ke waktu yang mengalami perubahan biologis, psikologis dan sosial yang berhubungan dengan penurunan daya tahan tubuh dan terjadinya penyakit, [12]. Menurut Pusat Data dan Informasi (2016), Lansia merupakan tahap akhir dimana pada siklus kehidupan ini mengalami kemunculan tanda - tanda penuaan. Terdapat peningkatan usia harapan hidup yang berdampak pada jumlah populasi tua yang bertambah pesat. Jumlah lanjut usia yang berusia 60 tahun atau lebih akan mengalami peningkatan dari 800 juta jiwa menjadi hampir 2 miliar jiwa pada tahun 2050, dengan peningkatan terbesar berada di negara berkembang, [10].

Berdasarkan Data Sensus Ekonomi Nasional Badan Pusat Statistik (BPS) (2017), mengatakan jumlah lansia yang ada di Indonesia yaitu 23,4 juta jiwa atau 8,97\%. Di tahun 2015 diperkirakan mencapai 33,7 juta jiwa atau 11,8\% dan di tahun 2035 diperkirakan sebanyak 48,2 juta jiwa dari jumlah penduduk di Indonesia atau 15,8\% (Profil Kesehatan Indonesia, 2012),[10]. Indonesia merupakan negara dimana jumlah penduduknya terutama lanjut usia yang sedang berkembang paling pesat di Asia Tenggara. Jumlah penduduk lansia terutama dibagian Jawa Tengah terus mengalami peningkatan. Berdasarkan hasil Sensus Penduduk (2015), jumlah penduduk lansia di Jawa Tengah sebanyak 3.983 juta orang. Jumlah penduduk lansia perempuan yaitu 2,132 juta jiwa lebih banyak dari jumlah penduduk lansia laki - laki yaitu 1,850 juta jiwa. Jika dilihat menurut kelompok umur, jumlah penduduk lansia terbagi menjadi 60 - 65 tahun sebanyak 1,343 juta jiwa, dan lansia lebih dari 65 tahun sebanyak 2,639 juta jiwa,[10].

Gangguan yang terjadi pada lansia yang diakibatkan dari peningkatan usia harapan hidup mempunyai dampak yang sangat signifikan. Pada umumnya masalah yang sering terjadi pada lansia adalah kecemasan. Kecemasan adalah kondisi emosi seseorang yang ditandai dengan perasaan tegang, pikiran cemas dan perubahan fisik, yaitu mengalami peningkatan tekanan darah, gemetar, dan lain - lain, [12]. Berdasarkan data statistik badan kesehatan dunia $(W H O)$, kecemasan meningkat sebesar $2,5 \%$ setiap tahunnya dengan perbandingan $2,43 \%$ pada wanita dan $0,07 \%$ pada lelaki. Di Indonesia angka kejadian gangguan kecemasan sekitar 39 juta jiwa dari 238 juta jiwa penduduk, [13].

Lansia yang mengalami kecemasan disebabkan oleh berbagai sumber, yaitu ancaman terhadap integritas fisik yang mengakibatkan ketidakmampuan fisiologis seseorang untuk melakukan aktifitas sehari - hari dan ancaman terhadap harga diri yang dapat merusak identitas diri dan integritas fungsi sosial, [12]. Beberapa dampak kecemasan yang tidak ditangani dengan baik, yaitu cenderung memiliki penilaian negatif tentang makna hidup, perubahan emosional dan gangguan psikosis, [11]. Akibat dari kecemasan pada lansia akan berakibat pada gangguan pendengaran, kesulitan mengingat dan sosial emosional, [3]. Umumnya penanganan kecemasan pada lansia menggunakan obat psikotropik.

Menurut Hocking \& Koening, obat psikotropik biasanya digunakan untuk mengatasi kecemasan pada lansia, akan tetapi penggunaanya beresiko mengalami penurunan pemulihan fisik, ketergantungan dan syndroma pemutusan obat. 


\section{Prosiding Seminar Nasional Kesehatan Lembaga Penelitian dan Pengabdian Masyarakat Universitas Muhammadiyah Pekajangan Pekalongan}

Pengobatan tersebut ada manfaat dan resiko yang harus dipertimbangan dengan penanganan lain. Yang harus diutamakan dalam pemberian terapi yang tidak berhubungan dengan obat terutama untuk pasien dengan tingkat kecemasan ringan sampai sedang adalah dengan kegiatan spiritual seperti dzikir, teknik relaksasi seperti relaksasi nafas dalam, dan teknik distraksi seperti terapi musik, [14]. Tujuan penulisan ini adalah untuk mengetahui pengaruh terapi musik gamelan Jawa terhadap tingkat kecemasan pada lansia di Desa Wanarata Kecamatan Bantarbolang Kabupaten Pemalang.

\section{Metode}

Rancangan penulisan ini yaitu studi kasus. Studi kasus (cese study) adalah salah satu jenis rancangan yang banyak dilakukan diberbagai bidang, [10]. Pengambilan data ini menggunakan lembar kuesioner, alat penelitian yang digunakan adalah Geriatric Anxiety Scale (GAS). Populasi studi kasus dalam penulisan ini adalah dua pasien lansia lebih dari 60 tahun yang mengalami kecemasan ringan dan sedang dengan pengaruh terapi musik gamelan Jawa terhadap tingkat kecemasan pada lansia. Variabel independen (bebas) dalam penulisan ini adalah terapi musik gamelan Jawa yang diberikan sebelum dan sesudah dilakukan tindakan, sedangkan variabel dependen (terikat) dalam penulisan ini adalah tingkat kecemasan pada lansia. Pengambilan data pretest dan posttest dilakukan pada Bulan Mei 2021. Pendokumentasian dalam penulisan ini yaitu pengkajian, diagnosa keperawatan, perencanaan, implementasi dan evaluasi, sehingga data tersebut dapat dipahami dalam menjawab masalah yang berkaitan dengan tingkat kecemasan pada lansia. Penyajian data dalam penulisan ini yaitu menjelaskan serta menggambarkan bagaimana hasil pengkajian sampai dengan evaluasi yang dilakukan pada dua pasien dengan pengaruh terapi musik gamelan Jawa terhadap tingkat kecemasan pada lansia di Desa Wanarata Kecamatan Bantarbolang Kabupaten Pemalang dimana data berupa subyektif dan obyektif dari klien, keluarga, perawat, pemeriksaan fisik, dan pemeriksaan penunjang.

\section{Hasil Dan Pembahasan}

\section{Hasil}

Hasil pengkajian pada kasus 1, yaitu klien berinisial Tn.K, berusia 65 tahun, berjenis kelamin laki - laki, suku Jawa, pendidikan klien SD, bekerja sebagai petani, bahasa dominan yang dipakai bahasa Jawa, status perkawinan cerai mati, alamat di Desa Wanarata Kecamatan Bantarbolang Kabupaten Pemalang. Klien mengeluh sakit kepala, berat badan klien $60 \mathrm{~kg}$, tinggi badan $170 \mathrm{~cm}$, tekanan darah 110 / 70 mmhg, pernafasan 20 x per menit, nadinya 90 x per menit, dan suhunya $36^{\circ} \mathrm{C}$. nilai kuesioner GAS klien (Terlampir) yaitu sebelum diberikan terapi 46 skor klien masuk kedalam tingkat kecemasan ringan (24-47). Klien mengatakan terkadang klien merasa kesepian dirumah sendirian karena cucunya sering bermain dengan teman - temannya diluar rumah. Klien tampak kesepian dan cucunya tampak tidak ada dirumahnya.

Hasil pengkajian pada kasus 2, yaitu klien berinisial Ny.U, berusia 63 tahun, berjenis kelamin perempuan, suku Jawa, pendidikan terakhir klien SD, bekerja ibu rumah tangga, bahasa dominan yang dipakai bahasa Jawa, status perkawinan 


\section{Prosiding Seminar Nasional Kesehatan Lembaga Penelitian dan Pengabdian Masyarakat Universitas Muhammadiyah Pekajangan Pekalongan}

menikah, alamat di Desa Wanarata Kecamatan Bantarbolang Kabupaten Pemalang. Klien mengatakan merasa lemas, berat badan klien $50 \mathrm{~kg}$, tinggi badan $150 \mathrm{~cm}$, tekanan darah 120 / 80 mmhg, pernafasan 22 x per menit, nadinya 88 x per menit, dan suhunya $36,5^{\circ} \mathrm{C}$. Nilai kuesioner GAS klien (Terlampir) yaitu sebelum diberikan terapi 43 skor klien masuk kedalam tingkat kecemasan ringan (24-47). klien juga mengatakan sering khawatir memikirkan anak - anaknya yang sudah berumah tangga karena semuanya jauh tempat tinggalnya diluar kota . Klien tampak terlihat khawatir.

Hasil dari pengkajian fokus dan analisa data yang muncul pada kasus 1 dan kasus 2 didapatkan diagnosa keperawatan : Ansietas. Fokus intervensi keperawatan pada kasus 1 dan kasus 2 dilakukan selama 3 hari berturut - turut, yaitu latih klien teknik distraksi untuk menurunkan ansietasnya yaitu dengan mendengarkan terapi musik gamelan Jawa laras slendro.

Fokus implementasi keperawatan pada kasus 1 dan kasus 2 yang dilakukan, yaitu melatih klien untuk menurunkan ansietasnya dengan teknik distraksi yaitu mendengarkan terapi musik gamelan Jawa laras slendro. Pada kasus 1 klien mengatakan sudah tidak merasakan kesepian lagi jika cucunya tidak dirumah, klien mengatakan senang dan tenang setelah diberikan terapi musik gamelan Jawa laras slendro, klien tampak senang dan tenang, klien tampak tidak terlihat kesepian lagi. Dan pada kasus 2 klien mengatakan sudah tidak merasakan khawatir lagi dengan anak - anaknya yang sudah berumah tangga yang tinggal diluar kota semuanya, klien mengatakan tenang dan nyaman setelah diberikan terapi musik gamelan Jawa laras slendro, klien tampak tenang dan nyaman, klien tampak tidak terlihat cemas lagi.

Evaluasi pada kasus 1 yang telah dilakukan yaitu klien mengatakan sudah tidak merasakan kesepian lagi jika cucunya tidak dirumah, skor GAS klien sebelum diberikan terapi musik gamelan Jawa laras slendro adalah 13 (Tidak mengalami kecemasan) dan skor GAS klien setelah diberikan terapi musik gamelan Jawa laras slendro adalah 9 (Tidak mengalami kecemasan), masalah Ansietas teratasi. Dan evaluasi pada kasus 2 yang telah dilakukan yaitu klien mengatakan sudah tidak merasakan khawatir lagi dengan anak - anaknya yang sudah berumah tangga yang tinggal diluar kota semuanya, skor GAS klien sebelum diberikan terapi musik gamelan Jawa laras slendro adalah 12 (Tidak mengalami kecemasan) dan skor GAS klien setelah diberikan terapi musik gamelan Jawa laras slendro adalah 11 (Tidak mengalami kecemasan), masalah Ansietas teratasi.

\section{Pembahasan}

Hasil penerapan ini menunjukkan bahwa terdapat pengaruh terapi musik gamelan Jawa terhadap tingkat kecemasan pada lansia di Desa Wanarata Kecamatan Bantarbolang Kabupaten Pemalang. Berdasarkan hasil penerapan pada kasus 1 dari skor GAS 46 menjadi skor 9 (Tidak mengalami kecemasan) dan kasus 2 dari skor GAS 43 menjadi skor 11 (Tidak mengalami kecemasan), maka terdapat perbedaan yang signifikan antara kecemasan lansia sebelum dan sesudah diberikan terapi musik gamelan Jawa. Adapun perbedaan pengkajian yang muncul antara kasus 1 dan kasus 2 yang mengalami ansietas dengan penyebab yang berbeda. Pada kasus 1 mengalami ansietas karena klien terkadang merasa kesepian dirumahnya karena cucunya sering 


\section{Prosiding Seminar Nasional Kesehatan 2021 Lembaga Penelitian dan Pengabdian Masyarakat Universitas Muhammadiyah Pekajangan Pekalongan}

bermain dengan teman - temannya diluar rumahnya. Dan pada kasus 2 mengalami ansietas karena klien sering merasa khawatir memikirkan anak - anaknya yang sudah berumah tangga semuanya karena semuanya tinggal diluar kota. Sesuai teori menurut Ayuningtyas (2012) mengatakan bahwa kecemasan pada lansia disebabkan oleh beberapa faktor penyebab, yaitu memikirkan penyakit yang diderita, merasa kesepian sehingga menyebabkan lansia mengalami susah tidur, kendali ekonomi, sedikit waktu berkumpul dengan keluarga, dan pikiran yang berlebih yang menyebabkan lansia merasa khawatir.

Pada kasus 1 hasil GAS sebelum diberikan terapi adalah 46 (Tingkat kecemasan ringan : 24-47) dari hasil point dominan yang klien jawab, klien menjawab sering mengalami kesulitan untuk memulai tidur, sering merasa gelisah, sering mengalami sakit leher. Dan pada kasus 2 hasil GAS sebelum diberikan terapi 43 (Tingkat kecemasan ringan : 24-47) dari hasil point dominan yang klien jawab, klien menjawab sering merasa gelisah, sering merasa lelah, sering merasa prihatin dengan anak - anak nya. Sesuai dengan teori yang dikemukakan oleh Segal (2010) dikutip dalam Yochim (2011) mengatakan bahwa GAS dibuat berdasarkan berbagai gejala kecemasan yang termasuk dalam manual diagnostik dan statistik gangguan mental pada lansia. Gejala gejala GAS tersebut antara lain gejala kecemasan afektif seperti menyesal, kesedihan mendalam, takut, nyeri dan ketidakberdayaan, khawatir, gelisah dan cemas, dll, gejala somatik seperti merasa pusing, merasa lelah, merasa sakit perut, dll dan gejala kognitif seperti merasa linglung, merasa tidak bisa mengendalikan kekhawatirkan, merasa prihatin, dll. Sehingga dapat terjadi perbedaan skor point yang dijawab oleh masing masing lansia. Oleh karena itu, pada kasus 1 point dominan yang dijawab lebih tinggi dari point dominan yang dijawab pada kasus 2 .

Hasil pengkajian pada kasus 1 dan kasus 2 diagnosa yang muncul adalah Ansietas. Pada kasus 1 dan kasus 2 memiliki persamaan diagnosa. Menurut teori Audrey B, Shirlee Snyder (2016) mengatakan bahwa ansietas atau kecemasan adalah perasaan yang tidak dapat dijelaskan yang disertai respon terhadap stimulus internal dan eksternal yang memiliki tanda dan gejala perilaku, afektif, kognitif dan fisik. Perasaan tidak tenang yang samar - samar karena ketidaknyamanan atau ketakutan yang disertai dengan ketidakpastian, ketidakberdayaan, isolasi, dan ketidaknyaman. Perasaan takut dan tidak menentu dapat mendatangkan sinyal peringatan tentang bahaya yang akan datang dan membuat individu untuk siap mengambil tindakan menghadapi ancaman, [14]. Berdasarkan batasan karakteristik dan faktor yang berhubungan, pada kasus 1 dan kasus 2 sesuai dengan hasil pengkajian ditemukan tanda dan gejala ansietas. Pada kasus 1 yaitu klien mengeluh sakit kepala, terkadang merasa kesepian dirumahnya karena cucunya sering bermain dengan teman temannya diluar rumahnya. Pada kasus 2 yaitu : klien mengatakan merasa lemas, sering khawatir memikirkan anak - anaknya yang sudah berumah tangga semuanya karena semuanya tinggal diluar kota. Sesuai dengan teori tanda dan gejala menurut NANDA (2018) mengatakan bahwa tanda dan gejala kecemasan antara lain mengeluh sakit kepala, mengeluh tidak nafsu makan, merasa lemas dan khawatir, gelisah, tampak tegang, sulit tidur dan tidak lelap, gangguan pencernaan, mengeluh takut, 


\section{Prosiding Seminar Nasional Kesehatan 2021 Lembaga Penelitian dan Pengabdian Masyarakat Universitas Muhammadiyah Pekajangan Pekalongan}

mengeluh cepat lelah, merasa tidak berdaya, gemetar, menangis, aktivitas sehari - hari terbengkalai, dan sulit berkonsentrasi.

Intervensi fokus untuk menurunkan kecemasan pada kasus 1 dan kasus 2 yaitu dengan teknik distraksi mendengarkan terapi musik gamelan Jawa laras slendro. Sesuai teori menurut Purwadi, mengatakan dengan musik yang diaplikasikan menjadi terapi, maka musik dapat meningkatkan, memulihkan, memelihara kesehatan spiritual, emosional, meningkatkan kesehatan psikologis yang dapat mengobati penyakit serta mengurangi kecemasan, [13]. Indikasi terapi musik gamelan Jawa yaitu sebagai berikut lansia yang mengalami insomnia, lansia yang mengalami kesepian, lansia yang mengalami kecemasan, dan lansia yang mengalami depresi dan stress. Terapi musik gamelan Jawa dilakukan selama 15 menit.

Implementasi keperawatan pada kasus 1 dan kasus 2 untuk menurunkan kecemasan yaitu melatih teknik distraksi mendengarkan terapi musik gamelan jawa laras slendro. Pada kasus 1 yaitu sudah tidak merasakan sakit kepala lagi, sudah tidak merasakan kesepian lagi jika cucunya tidak dirumah, skor GAS sebelum diberikan terapi 46 (tingkat kecemasan ringan) setelah diberikan terapi turun menjadi skor 9 (tidak mengalami kecemasan), sedangkan pada kasus 2 yaitu sudah tidak merasakan gelisah lagi, sudah tidak merasakan khawatir lagi dengan anak - anaknya yang sudah berumah tangga semuanya, skor GAS sebelum diberikan terapi 43 (tingkat kecemasan ringan) setelah diberikan terapi turun menjadi skor 11 (tidak mengalami kecemasan). Pada kasus 1 dan kasus 2 memiliki perbedaan pada hasil skor GAS. Sesuai dengan teori yang dikemukakan oleh Yochim (2011) mengatakan bahwa GAS dibuat berdasarkan berbagai gejala kecemasan yaitu gejala kecemasan afektif seperti menyesal, kesedihan mendalam, takut, nyeri dan ketidakberdayaan, khawatir, gelisah dan cemas, dll, gejala somatik seperti merasa pusing, merasa lelah, merasa sakit perut, dll dan gejala kognitif seperti merasa linglung, merasa tidak bisa mengendalikan kekhawatirkan, merasa prihatin, dll. Sehingga dapat terjadi perbedaan skor point yang dijawab oleh masing - masing lansia. Oleh karena itu, gejala GAS tersebut memiliki perbedaan yang signifikan antara kasus 1 dan kasus 2 yang mempengaruhi terjadinya penurunan kecemasan pada lansia sebelum dan sesudah diberikan terapi musik gamelan Jawa.

Hasil evaluasi dengan terapi musik gamelan Jawa laras slendro pada kasus 1 dan kasus 2 sama - sama mengalami penurunan kecemasan, yaitu pada kasus 1 sudah tidak merasakan kesepian lagi jika cucunya tidak dirumah, dari skor GAS 46 (tingkat kecemasan ringan) menjadi skor 9 (tidak mengalami kecemasan). Dan pada kasus 2 sudah tidak merasakan khawatir lagi dengan anak - anaknya yang sudah berumah tangga yang tinggal diluar kota semuanya, dari skor GAS sebelum diberikan terapi 43 (tingkat kecemasan ringan) setelah diberikan terapi turun menjadi skor 11 (tidak mengalami kecemasan. Masalah Ansietas pada kasus 1 dan kasus 2 teratasi.

Sesuai dengan jurnal penelitian yang mendukung yaitu Yusli (2018) pengaruh pemberian terapi musik gamelan Jawa terhadap tingkat kecemasan lansia di Rumah Pelayanan Sosial lanjut usia Pucang Gading Semarang. [14]. Mendengarkan musik gamelan Jawa tempo lamban atau sekitar 60-100 bpm dapat memperlambat dan menyeimbangkan gelombang otak yang menandakan ketenangan. Keadaan tenang 


\section{Prosiding Seminar Nasional Kesehatan Lembaga Penelitian dan Pengabdian Masyarakat Universitas Muhammadiyah Pekajangan Pekalongan}

yang dirasakan seseorang akan memiliki beta karbolin, yaitu antagonis GABA yang menyebabkan penurunan jumlah down regulator receptor GABA. Penurunan ini yang akan mengurangi hambatan terhadap timbulnya kecemasan, [6].

\section{Kesimpulan Dan Saran}

Kesimpulan yang dapat diambil dari studi kasus yang dilakukan adalah ada pengaruh pemberian terapi musik gamelan Jawa di Desa Wanarata Kecamatan Bantarbolang Kabupaten Pemalang untuk menurunkan kecemasan. Pada kasus 1 dari skor GAS 46 menjadi skor 9 (Tidak mengalami kecemasan) dan kasus 2 dari skor GAS 43 menjadi skor 11 (Tidak mengalami kecemasan). Berdasarkan hasil penerapan tersebut maka disarankan perawat dapat memberikan terapi musik gamelan Jawa untuk menurunkan kecemasan pada lansia.

\section{Referensi}

[1] Aspiani, R. (2014), Asuhan Keperawatan Gerontik Aplikasi Nanda, Nic dan Noc Jilid 2. Jakarta : CV.TRANS INFO MEDIA.

[2] Daryani. (2014). Pengaruh Terapi Musik Langgam Jawa Terhadap Penurunan Tingkat Kecemasan Pada Lansia Di Purworejo. Jurnal IImu Keperawatan, 9(1), 12. Retrieved from http://ejournal.stikesmukla.ac.id/index.php/triage/ article/view/187

[3] Direja, A. (2017), Asuhan Keperawatan Jiwa. Yogyakarta : Nuha Medika.

[4] Hadi, R. (2013). Pengaruh Intervensi Musik Gamelan Terhadap Depresi Pada Lansia Di Panti Wreda Harapan Ibu, Semarang. Jurnal Keperawatan Komunitas, 1(2), 104538.

[5] Hidayat, S., Aliftitah, S., \& Fadilla, M. (2017). Terapi Musik Gamelan Madura Terhadap Tingkat Depresi Pada Lansia Di Desa Talango. Journal of Chemical Information and Modeling, 53(9), 1689-1699. file:///C:/Users/User/Downloads/fvm939e.pdf

[6] Maas, M. (2011). Asuhan Keperawatan Geriatrik. Jakarta : EGC.

[7] Noor, Z., \& Junaidi. (2010). Penurunan Tingkat Kecemasan Pada Lansia Melalui Terapi Musik Langgam Jawa. Jurnal Keperawatan Indonesia, 13(3), 195-201.

[8] Prabowo, E. (2018), Konsep \& Aplikasi ASUHAN KEPERAWATAN JIWA. Yogyakarta : Nuha Medika.

[9] Ratnawati, E. (2017), Asuhan Keperawatan Gerontik. Yogyakarta : PUSTAKA BARU PRESS.

[10] Rindayati, R., Nasir, A., \& Astriani, Y. (2020). Gambaran Kejadian dan Tingkat Kecemasan pada Lanjut Usia. Jurnal Kesehatan Vokasional, 5(2), 95. https://doi.org/10.22146/jkesvo.53948

[11] Sawitri, E. (2018). Hubungan spiritualitas dengan kecemasan pada lansia. Motorik, 13(27).

[12] Sutejo. (2019), Keperawatan Jiwa Konsep dan Praktik Asuhan Keperawatan 


\section{Prosiding Seminar Nasional Kesehatan Lembaga Penelitian dan Pengabdian Masyarakat Universitas Muhammadiyah Pekajangan Pekalongan

Kesehatan Jiwa : Gangguan Jiwa dan Psikososial. Yogyakarta : PUSTAKA BARU PRESS.

[13] Widiastuti, R. (2013). Pengaruh Intervensi Musik Gamelan Terhadap Depresi Pada Lansia Di Panti Wreda Harapan Ibu, Semarang. Jurnal Keperawatan Komunitas, 1(2), 135-140. Retrieved from http://jurnal.unimus.ac.id/ index.php/JKK/article/view/991

[14] Yusli, U. D., \& Rachma, N. (2018). Pengaruh Pemberian Terapi Musik Gamelan Jawa terhadap Tingkat Kecemasan Lansia di Rumah Pelayanan Sosial Lanjut Usia Pucang Gading Semarang. Jurnal Perawat Indonesia, 3(1), 72-78.

[15] Zaini, M. (2019), Asuhan Keperawatan Jiwa Masalah Psikososial Di Pelayanan Klinis dan komunitas. Yogyakarta : Grup Penerbitan CV BUDI UTAMA. 